\title{
Disclosing discoveries
}

\author{
Renee Kaswan \\ Toiling away at the university, you've just made your once-in-a-lifetime discovery. Here's how to survive what comes next.
}

\begin{abstract}
$\Delta \mathrm{h}$, your big scientific breakthrough! A This should be your moment of triumph. A patent, recognition, tenure, wealth and scientific advancement for the good of mankind-indeed, all of this is possible. But there's an alternative world, too: aggressive intellectual property (IP) lawyers, lawsuits and the university claiming ownership with sole discretion and total authority over the destiny of your invention.

Commercializing an invention for any independent researcher is a journey fraught with challenges, whether working outside or inside a university system. And as your invention increases in value, the risks and difficulties in IP transfer increase. But if you aspire to be an inventor-entrepreneur, a good university technology transfer office (TTO) can and will support you as you bootstrap your start-up. This article explains how to navigate these waters.
\end{abstract}

But the first step is to take stock of your interests, skills and limitations. Do you really want to be an inventor-entrepreneur? Would you relinquish tenure and leave the university to develop your discovery? For your particular project, are the resources available to you within the university system more valuable than autonomy? Before answering, remember this: an idea is a far cry from a product or business, and most companies fail, so don't be too quick to give up your day job.

If you do choose independence, your next step is to determine how to manage the rights to the IP you have created. Most US schools have compulsory IP assignment policies. Before you or others invest time and money to make your discovery successful, secure a written waiver of assignment from the university. Otherwise, as the value of your IP rises so will the threat of litigation.

Renee Kaswan is founder of IP Advocate,

Atlanta, Georgia, USA.

e-mail: rkaswan@ip-advocate.org

\section{Dealing with Bayh-Dole}

Perhaps the biggest challenge to researchers is that most universities misinterpret and/or misapply the federal law that governs how they commercialize inventions. The BayhDole Act of 1980 was written by lawyers representing university technology transfer programs with the intent of promoting commercial investment into research and thus enabling the use of federally supported inventions. In this way, the benefits would become available to the public who funded the research. The act permitted universities to obtain titles to federally supported discoveries and serve as stewards of patentable inventions produced by faculty and other research personnel. This is very unlike conducting research at a company (Box 1).

Although Bayh-Dole requires that the university act as coordinator for inventions made with federal funds by its personnel, it does not require that the university own this IP or act as the sole means of commercialization. But most universities implement the act by compelling faculty and other research inventors-and sometimes students-to disclose their inventions to the institution's TTO and then require them to assign patent applications to the university's exclusive ownership. Most schools use this same approach for all inventions-whether federally funded or not. In general, as a researcher at the school you are compelled to comply, although each school's policies and practices differ.

The requirement for faculty to place all inventions with a single office on campus (a few universities do have a separate office for biomedical inventions) creates a bureaucratic bottleneck by making all faculty inventors subject to the same, often overworked or underfunded, staff. That same policy effectively squeezes inventions of all sorts, from biotech and nanotechnology to software through the same office.

This leaves you at their mercy. Woe to you if the university's TTO is low on funds for the year and does not want to pay a patent application fee or if it just lost its licensing officer for biotech to a better offer. Your discovery will languish. This is just one of many pitfalls you must watch out for (Box 2).

The fact is that technology transfer is a challenging job and one that has long odds no matter who is doing it-university TTO, inventor or otherwise. Still, the TTO can be a valuable partner and resource for you, and many technology transfer managers take a collaborative approach from the start, working diligently to bring innovations to market in partnership with the academic inventor. But the relationship is essentially a 30 -year marriage to the institution-and the institution's legal counsel generally regards you as a mere corporate employee. Make certain your equity rights are well documented long before your active participation becomes unnecessary.

\section{Prepare yourself}

The most important actions you can take are to educate yourself and remain engaged in the process. Knowledge is key, and you will have the most control over the process before you disclose your discovery. So learn the ropes before disclosing or signing anything.

In this vein, get to know your TTO and its people before you need them. Start with an informal meeting with the TTO or invite someone from the office to give a talk to your group. Ask a lot of questions; get a feel for how they work. Assemble the documents you'll need to prepare for legal review and dissect them. You might want to insert addenda or strike out clauses in order to protect your laboratory's interests in the IP rights. You'll want your employment agreement, research contracts, the university's IP and conflict-of-interest policy, the state law on employer claims on inventions and any sponsored research conditions, including Bayh-Dole.

Many IP policies are contracts of adhesion, meaning they provide a unilateral right 


\section{Box 1 Faculty versus corporate research}

Unlike corporate employees, university faculty are "hired to conduct research" not "hired to invent." Corporations assign research projects specifically to their employees, whereas faculty are encouraged to initiate their own research ideas and innovations.

Corporations fund their employees' research programs, and therefore the shareholders are the rightful beneficiaries of the intellectual property produced. Taxpayers fund research through federal research grants, so it is appropriate for the government to hold universities accountable for being proactive in managing inventions-if a university chooses to manage inventions - and have them benefit the public.

The American Association of University Professors' charter describes the public benefits of these fundamental principles of academic freedom for research and free speech. The Association, as well as regulation of academic freedom, began in the 1940 s in reaction to the widespread political corruption of the academic mission to seek and disseminate knowledge.

For better or worse, in 1980 when Congress passed the Bayh-Dole Act, universities added the function of technology transfer to their traditional role of cultivating knowledge. By including intellectual property trustee and clearinghouse functions, academia's mission and responsibilities became more confounded.

for the university to make changes without requiring consent of the inventors. So if you are satisfied with the present IP policy, get the director of technology to sign an agreement stating that your rights in your disclosed invention cannot be altered without your written, voluntary consent.

Inventors who want to protect their ownership rights in their property can draft (or have a lawyer draft) a memorandum of agreement, or memorandum of understanding, and then make it an addendum to the standard invention disclosure agreement. Without your signature on this transfer of ownership, the university cannot sell or license your invention to anyone else.

The transfer of title for the patent application and issued patent must be registered at the US Patent and Trademark Office. Legal ownership change occurs in this assignment contract, and this is the point at which the property title is transferred. Think of this as transferring the title of your car: you sign the title assignment with the state but you have the bill of sale with the dealer on the price paid. The federal assignment form that transfers an inventor's constitutional ownership rights to another party is, by federal law, made 'for due consideration', and that inventor can determine what that 'consideration'payment, in other words-is going to be; it would be foolish to give any employer carte blanche to define the payment.

Your consideration can be: participation in contract negotiations, veto power over license decisions, income for the laboratory, consultant salary for you, revocation of patent assignment for unmet diligence requirements, right to audit the university and licensee, administrative dispute resolution procedures, right to create a start-up company and license your own invention at nominal cost, definition of net income, right to publish, right to open source your invention or right to place your invention with an independent agent, such as GreenCentre (http:// www.greencentrecanada.com/) or Science Commons (http://sciencecommons.org/).

You should determine what rights you hope to safeguard for your laboratory, your research, your students and yourself before you ever disclose a discovery to the TTO. Be mindful of the propensity to underestimate the unknown. Because of differing perspectives and experiences, your impression of the relative value of your invention versus the difficulties and expense to commercialize it will be quite different than the TTO's. Neither of you is sure of what the other knows or doesn't know, so use finesse, or else egos can collide.

For intercollegiate research, steer the invention to the TTO that best serves your commercialization goals. Some researchers invite a colleague from another university to participate in their research to get access to their office and avoid their resident one. If you are working with a researcher or group from another university, carefully look at both TTOs before deciding which to approach.

\section{Understand your rights}

So, the rights to your invention originally reside with you - the US Constitution makes that pretty clear. Technology transfer officers generally claim the university will own the patent rights to all federally funded research based upon the Bayh-Dole Act. Even so, a recent US Court of Appeals for the Federal Circuit decision ruled that the Bayh-Dole Act did not grant universities automatic ownership of federally funded research. In the case of Board of Trustees of the Leland Stanford Junior University v. Roche Molecular Systems, Inc., et al., which involved patents for HIV test kits using PCR, the court rejected Stanford's argument that one of the co-inventors' assignment of rights to another entity, Cetus (Emeryville, Calif., no longer in business), was voided by the university's rights to federally funded inventions under the Bayh-Dole Act. The court's ruling states: "Bayh-Dole does not automatically void $a b$ initio [from the beginning] the inventors' rights in government-funded inventions." This case may be appealed, so stay tuned.

Even so, the court's decision means the university must have a contract with the inventor to get rights-the Bayh-Dole Act doesn't change that. This does not mean you should automatically fight your university for rights to your invention. Truthfully, you need one another, and although withholding your signature on title assignment is your leverage, their leverage is firing you, harassing you or suing you. Many universities have sued students and faculty who refused to sign patent assignments (for more information, see http://www.ipadvocate.org/forum/ dispute.cfm?Type=Disputes). It is not advisable to go to war with your employer, and if you won't sign a transfer of title and they won't waive their rights to title, you'll likely fall into a stalemate situation.

Unfortunately for academic inventors, most courts give the university great latitude and presumption of rights because they are nonprofit public institutions. Faculty and student inventors usually lack the financial resources to outlast the legal gamesmanship.

If you decide you don't want to work with your TTO, figure out what policy and contractual exceptions might apply to your situation before you make any disclosures. Your funding proposals may already have designated ownership of future IP; a seasoned principal investigator will coordinate contractual ownership from the earliest stages.

Early on, administrative dispute resolution procedures may be successful in getting a waiver of your IP rights. Beware, though, because once there is significant money at stake, many corporate-style board members and administrators will circumvent their institution's IP policies and send all decisions and interactions to ruthless litigators. At which point, as a researcher without deep pockets behind you, you will be at a serious disadvantage.

\section{Narrow your scope}

When you apply for research funding, carefully define the scope of your work. This 
helps avoid confusion later about whether or not a particular discovery was made with government funds and helps clarify the resulting questions about ownership.

For federal funding, read the implementing regulations to the Bayh-Dole Act at 37 CFR 401.1 (you can find that online) for information about how the scope of "planned and committed" activities dictate what is a "subject invention"-that is, an invention covered by Bayh-Dole. Drafting objectives toward science, not applications, leaves inventions of applications outside the scope of the federal funding arrangement.

Next, be sure you know your university's IP policy. It's usually incorporated by reference into your employment contract. Some policies specify that you must disclose all inventions, whereas others are more flexible. Some require all employees to agree to assign rights to future inventions to the university, and following the recent Stanford $v$. Roche case, many are incorporating new language: "I hereby assign." If you can't avoid agreeing to assign, work to narrow the scope of obligation or change the burden of proof on making determinations. Typically, those conditions will be qualified with whatever is agreed to in a research contract.

When determining scope of obligation, ask yourself these questions: Is the invention within the planned and committed activities of the research? If it's not, then is it within the academic responsibilities under your employment contract (thus, could it be part of consulting)? If it is not expressly part of your academic duties, then have you made significant use of university facilities when you didn't have to? Is the invention covered in exclusions under state labor law (which may limit employer claims on inventions, even those making use of facilities)? If you anticipate that you will need to circumvent claims of ownership by the resident university, make choices that will bolster your claim on your invention and discourage a lawsuit against you.

After you've decided to make the disclosure to your university, the TTO reviews it to see if it meets the requirements of Bayh-Dole, and then the TTO decides how it wants to proceed. A TTO can always decline to manage a particular innovation. For federally supported inventions, the option to manage patent rights may then go to the agency that sponsored your research, and from there, to the public domain (if no application is filed), to agency licensing programs (if the agency decides to obtain the title) or to the inventor (if the inventor requests the title and demonstrates the capacity to use the invention in the public interest). Currently, university

\section{Box 2 Eyes wide open}

Be aware of these potholes in your path from university discovery to start-up success: The full life cycle of commercialization can take up to 30 years, during which time technology transfer office (TTO) staff-and university administration-will come and go. You will need to be aware of any changes.

There are generally no performance requirements that would keep the TTO accountable to its inventors, so there is little recourse for faculty or students if the TTO is underperforming (for example, if the TTO has an unreasonable duration to review a disclosure and forward it to patent counsel or release a legal waiver to the inventors).

You are typically promised a share of royalties based on a verbal commitment that the TTO will be diligent in patenting and marketing your invention. This obviously leaves you vulnerable and at the mercy of the TTO.

TTOs often take a 'just in case' approach - they tend to claim control of all inventions that appear to have potential value rather than just the ones they have the resources and ability to commercialize. Conflicts arise whenever the TTO is uncertain or afraid to make an error in deciding to either commit limited financial support or release the invention back to the researchers.

Successful intellectual property draws a lot of attention, which can often be harmfulcorporations sometimes pirate, stall or challenge rather than purchase intellectual property rights. Universities and small start-ups are easily outmaneuvered by so-called patent assassins, opportunist litigators (both their own and their opponents') and corporate business schemers.

A university partner with political clout can be invaluable when unexpected obstacles are thrown your way. However, if that political engine litigates against you, success becomes very elusive indeed. Be certain your alliance is legally secured before challenges arise.

requests to award the title to the inventor are approved expeditiously by most federal granting agencies.

If you want ownership and your research was federally funded, ask for help getting the waiver you need for personal ownership. If it was funded by a foundation, talk to the program officer and enlist his or her support to obtain ownership, perhaps with a conditional deal, such as, "If I get personal ownership, we will work together."

The TTO staff is unlikely to have the exact experience your discovery meritsespecially if the invention is transformative new science. The goal here is not to find that elusive 'perfect match' of a TTO that understands your invention exactly-that's virtually impossible. You should be doing this as part of ongoing negotiations with your TTO. You'd be wise to reveal the minimum necessary to accomplish your task at hand, whether working with the university or a corporate sponsor. The balance between paranoia and naivety is precarious. Don't get fooled into giving away valuable information because of a few ego strokes.

The goal is to discover what your commercialization partners know and fill any gaps as needed-on all sides. A biotech researcher may not necessarily know the business world, just as your tech transfer specialist may not fully comprehend the significance of your work. But a good tech transfer manager will know how to assemble the right expertise for a deal ahead of the transaction. You should ask whether you can help identify a team to work on the invention in collaboration with the TTO.

\section{Get it in writing}

Write out your understanding of what the TTO has agreed to do as a memorandum of understanding and give it to the TTO. Then request that they make any corrections and return it to you. It's not necessarily legally binding but at least everyone's expectations will be in writing.

Another option is to approach the TTO-on behalf of the team you lead-and ask for help drafting a participation agreement. This assigns a portion of income and governance of research commercialization decisions back to the principal investigator and laboratory team under rules they have adopted up front. After all, welldesigned participation agreements build strong laboratory programs by attracting further funding, top students and quality faculty. The participation agreement sets the ground rules for everyone involved. The TTO may support this approach, and it doesn't necessarily put anyone on the defensive, so work gets done faster and closer to the goals you set because the aim is to clarify the next steps for everyone.

If the TTO doesn't seem like a good fit, examine other options. Perhaps you can collaborate with a co-investigator at a university with a more favorable TTO and that office can take the lead. 
To set this up, consider subcontracting a bit of research to that school or creating a collaboration. Joint inventions can migrate to the other school, but make sure they want to deal with you and also that your colleague there is reliable. Consult your research contract to make sure there's no downside.

An inventor can file for a provisional patent for $\$ 150$ for one year to buy time to sort out the details. The provisional patent application (Supplementary Note) will not be published, so the invention will not be exposed to competitors. If you happen to publish your work, the provisional patent protects the invention's priority for patenting, but only if it clearly teaches the invention so that one with ordinary skill in the art can practice it without undue experimentation-that is, only if the application enables the invention. The provisional patent is hardly a panacea, but it can be used discriminately. Filing a provisional patent may trigger a university's disclosure requirement, and it could constitute conflict of interest if you don't disclose-so be careful.

If the university really wants your signature assigning all rights, ask if they will provide legal representation to you to make sure your interests-and those of any others working with you-are protected. But even when all parties are collaborative and friendly, the fact is, it's their policy and their terms, written by their lawyersall in regard to your IP.

And make sure your grad students have their own legal representation; they shouldn't rely on yours. A good TTO will respect this. But take care in how you present the request-if it's adversarial rather than transactional you'll only invite pain in the form of legal hassles.

\section{Collaboration works best}

You are an expert on your invention-it's your creation, after all. Without your enthusiastic cooperation, it is highly unlikely the licensing officer can or will proceed to commercialize your invention. But you're likely not an expert on the legal or business side of things. So be courteous, realistic and reasonable, but still work out terms you can be satisfied with no matter who takes over the reins of the technology licensing office.

Your own dedication to your cause and tenacity in pursing your goals are your best assets throughout commercialization.

Note: Supplementary information is available on the Nature Biotechnology website.
To discuss the contents of this article, join the Bioentrepreneur forum on Nature Network: http://network.nature.com/groups/bioentrepreneur/forum/topics 